3. И. Саляхова. Способы образования принадлежности имен существительных в башкирском и казахском языках

Научная статья

УДК 811.512 .141

DOI: $10.18101 / 2305-459 X-2020-4-53-57$

\title{
СПОСОБЫ ОБРАЗОВАНИЯ ПРИНАДЛЕЖНОСТИ ИМЕН СУЩЕСТВИТЕЛЬНЫХ В БАШКИРСКОМ И КАЗАХСКОМ ЯЗЫКАХ
}

\author{
(C) Саляхова Зугура Идрисовна \\ доктор филологических наук, доцент, \\ заведующая кафедрой башкирской филологии, \\ Стерлитамакский филиал Башкирского государственного университета \\ Россия, 453103, г. Стерлитамак, пр-т Ленина, 49 \\ s.zuhra@hotmail.com
}

\begin{abstract}
Аннотация. Статья посвящена исследованию категории принадлежности имен существительных в башкирском и казахском языках. И в башкирском, и в казахском языках категорией принадлежности называют грамматическую категорию, выражающую одновременно и предмет обладания, и лицо обладателя, связанное с одним из трех лиц, которые обозначаются посредством личных местоимений. В статье рассматриваются показатели и способы образования значения принадлежности имен существительных. Анализируется морфологическое выражение принадлежности, которое выражается специальными аффиксами. Исследуется морфолого-синтаксический способ выражения категории принадлежности имен существительных, характеризующихся местоимениями и аффиксами принадлежности. В тюркских языках, в том числе и в башкирском, и в казахском языках, конкретная принадлежность может выражаться и другими способами. Кроме того, существует так называемая абстрактная принадлежность, которая выражает свою принадлежность отдельно от того предмета, на который она могла бы быть направлена.

Ключевые слова: башкирский язык; казахский язык; морфология; имя существительное; категория принадлежности; аффикс; морфолого-синтаксический способ образования слов.
\end{abstract}

\section{Для цитирования}

Саляхова 3. И. Способы образования принадлежности имен существительных в башкирском и казахском языках // Вестник Бурятского государственного университета. Язык. Литература. Культура. 2020. Вып. 4. С. 53-57.

В тюркских языках, в том числе в башкирском и казахском языках, части речи имеют общее семантическое содержание и грамматические свойства. При классификации частей речи в тюркских языках учитываются следующие показатели: семантический, синтаксический, формальный. Как известно, части речи подразделяются на самостоятельные и служебные. Самостоятельные части речи обладают лексическими категориями с семантико-формальными показателями, образуют группы слов, объединенные общими семантическими и формальными признаками (имя существительное, имя прилагательное, имя числительное, местоимение, наречие, глагол). 
Имя существительное и в башкирском, и в казахском языке обозначает названия социальных явлений, явлений природы, названия действий и движений, одушевленных и неодушевленных предметов. Основное грамматическое значение имен существительных - это обозначение предметности. Средством выражения грамматической предметности являются морфологические категории имен существительных.

Для имен существительных башкирского языка (исем) характерны морфологические категории: категория принадлежности (эйәлек категорияһы); категория сказуемости (хәбәрлек категорияһы); категория числа (hан категорияһы) и лица (зат категорияһы); категория падежа (килеш категорияһы); категория определенности и неопределенности (билдәлелек һәм билдәһезлек категорияһы). Для существительных (зат есім) казахского языка свойственны грамматические категории множественного числа (көптік категориясы) и лица (жекелік және); категория принадлежности (тәуелдік категориясы); категория падежа (септік категориясы).

Категория принадлежности в языкознании в широком плане именуется термином изафет. В тюркских языках изафетом называют особые именные конструкции, состоящие из двух существительных, связанных друг с другом каким-либо отношением. Сначала идет «определяющее слово», затем «определяемое слово». В башкирском языке, например: ауыл урамы (улица деревни), мәктәп баксаһы (сад школь), фатир хужаһы (хозяин квартиры). В казахском языке: үйдің терезесі (окно дома), мектептің асханасы (столовая школы), пәтер иесі (хозяин квартиры).

В башкирском и казахском языках категорией принадлежности называется грамматическая категория, выражающая одновременно и предмет обладания, и лицо обладателя, связанное одним из трех лиц, которое обозначаются посредством личных местоимений [4, с. 60]. В башкирском языке дусь-ымм (мой друг) мы различаем два элемента: предмет обладания, выраженный основой $\partial c_{c}-$, и имя обладателя, выраженное аффиксы принадлежности -ылм (мой). Форма дус̧ымм выражает так называемую конкретную принадлежность, поскольку она дает понятие не только о самом отношении (мой), но и о том предмете, на который это отношение распространяется. Соединение этих двух моментов в форме одного слова и составляет морфологическую категорию конкретной принадлежности $[4$, c. 60]. Нужно отметить, что и предмет обладания, и лицо обладателя могут употребляться в языке в единственном и во множественном числе.

Категория принадлежности имен существительных в башкирском и казахском языках выражается морфологическим и морфолого-синтаксическим способами.

1.Морфологический способ выражения принадлежности в башкирском языке.

Категория принадлежности имеет морфологическое выражение путем присоединения специальных аффиксов к основам, оканчивающимся на согласную основу:

- 1-е лицо, единственное число: -ыlм, -ем, -ом, -өм (дусь-ым “мой друг”, дәфтәр-ем "моя тетрадь”), множественное число: -ыбызз, -ебез, -обоз, -өбөз (дусьббзз “наш друг”, дәфтәр-ебез “нама тетрадь”); 
3. И. Саляхова. Способы образования принадлежности имен существительных в башкирском и казахском языках

- 2-е лицо, единственное число: -ың,, -ещ̧, -он, -өң (дус̧-bıң “твой друг”, дәфтәр-ең “твоя тетрадь”), множественное число: -ығызз, -егез̧, -огоз, -өгөз (дусьыцъьзз “ваш друг”, дәфтәр-егез “вама татрадь”);

- З-е лицо, единственное число: -bl, -е, -о, -ө (дусь-ыl “его друг”, дәфтәр-е “ее тетрадь”), множественное число: -тары, -тәре, -дары, -дәре, -зары, -лары (дусьтары “их друг”, дәфтәр-ззре “их тетрадь").

Основы, оканчивающиеся на гласную основу, принимают следующие аффиксы принадлежности:

- 1-е лицо, единственное число: -м (бала-м “мой ребенок”, бүлмд-м “моя комната”), множественное число: -быз, -без̧, -боз, бөз (бала-быз “наш ребенок”, бүлмд-без “наша комната");

- 2-е лицо, единственное число: -ңз (бала-ң “твой ребенок”, бүлмә-цุ “твоя комната"), множественное число: вызз, -гез, -гоз, -гөз (бала-гыз “ваш ребенок”, бүлмә-гез “вача комната");

- 3-е лицо, единственное число: -hbl, -he, -ho, -hө (бала-hbl “его ребенок”, бүлмә-hе "ее комната"), множественное число: -лары, -ләре (бала-лары “их ребенок”, бүлмә-ләре “их комната").

2. Морфологический способ выражения принадлежности в казахском языке.

Категория принадлежности в казахском языке выражается при помощи окончаний принадлежности - тәуелдік жалzау. Такую конструкцию существительное + аффикс принадлежности называют притяжательной формой имен существительных. Так же как и в башкирском языке, в казахском языке после гласных и согласных используются разные варианты формообразующего аффикса:

- 1-е лицо, единственное число: -ылм/-ім/-м (дос-ылм “мой друг”), дәптер-ім “моя тетрадь”, множественное число: ылмыз/-іміз, -мыз/-міз (дос-ылмыз “наш друг”, дәптер-іміз “нама тетрадь”);

- 2-е лицо, единственное число: -ырџ/-ің/-ц (дос-ыңщ “твой друг”, дәптер-ің

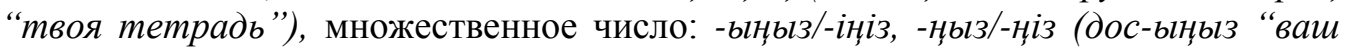
друг”, дәптер-іңіз “ваша тетрадь”);

- 3-е лицо, единственное число: -bl/-i, -cbl/-ci (дос-ыl "его друг”, дәптер-i “его тетрадь”), множественное число: -bl/-i, -cbl/-ci (дос-тар-bl "их друг”, дәптер-лер-і “.

При морфолого-синтаксический способе выражения принадлежности в башкирском языке работают местоимения минең (мой, моя), Һинең (твой, твоя), уның (его, ее), без̧ец (наш), һез̧зең (ваш), уларзың (их) и специальные аффиксы принадлежности. Например: минең юл+ым “моя дорога", һинең юльь ың “твоя дорога", уның юл+ы “его дорога", без̧зең юл+ыбыз “наша дорога", һез̧зеең юл+ыzыз “ваша дорога", уларзың юл+дары “их дорога”.

Примечательно, что в казахском языке формы принадлежности при морфолого-синтаксическом способе образуются аналогичным способом, т. е. с помощью местоимений менің (мой, моя), сенің (твой, твоя), оның (его, ее), біздің (наш), сіздің (ваш), олардың (ux) и путем присоединения к имени существительному аффиксов принадлежности. Например: менің құлам+ым "моя ручка", сенің әке+н “твой отеи”, оның үй $+i$ “его дом”, біздің мектеб+іміз “нама школа”, сіздің жол+ыңыз “ваша дорога”, біздің достар+ылмыз “наши друзья”. 
Интересно, что в башкирском языке конкретная принадлежность кроме морфологического $(\partial y c+b l м, \partial o c+b l м)$ и морфолого-синтаксического способа $(м и н+е ц \partial y c+b l м, м е н+i ң \partial o c+b l м)$ может выражаться и синтаксическим способом. Например: мин ең дус “мой друг”, һин+ең катьын “твоя супруга”, без̧+з̧ең бала "наш ребенок".

Нужно отметить, что существует так называемая абстрактная принадлежность [4, с. 60], которая выражает свою принадлежность отдельно от того предмета, на который она могла бы быть направлена. В башкирском языке такая форма принадлежности образуется с помощью прибавления аффиксов -ныкы, -неке, -зыкы к личным местоименям (минеке, һинеке, уныкы, беззеке, hез̧зеке, уларзыкы). Например: Был дәфтәр минеке "Эта тетрадь - моя". Был өй һинеке "Этот дом - твой". Был сәска уныккы "Этот иветок ее”. Был китап без̧зеке "Эта книга наша". Ул һыйыр һез̧зеке "Та корова ваша". Был ауыл уларзыкы букв.: “Эта деревня их”.

В казахском языке также существует особая форма принадлежности, которая образуется с помощью аффиксов -нікі/-дікі/-тікі (менікі, сенікі, оныкі, біздікі, сіздікі, олардікі). Местоимения менікі, сенікі, оныкі, біздікі, сіздікі, олардікі в данном случае выступают в роли сказуемого. Например, Бұл дәптер менікі “Эта тетрадь моя”. Мынау сыйльққ сенікі “Этот подарок твой”. Осы үстел оныкі “Это стол его”. Мынау мектеб біздікі “Эта школа - наша”. Бұл кітап сіздікі “Эта книга - ваша". Мынау қалам олардікі “Эта ручка ваша".

Таким образом, в башкирском и казахском языках категорией принадлежности называется грамматическая категория, выражающая одновременно и предмет обладания, и лицо обладателя, которые обозначаются посредством личных местоимений. В башкирском языке: минең дәфтәр-ем “моя тетрадь”, в казахском языке: менің дәптер-ім “моя тетрадь”, мы различаем два элемента: предмет обладания, выраженный основой дәфтәр/дәптер, и имя обладателя, выраженное аффиксом принадлежности -blм; -blм/-iм/-м (мой). Форма дәфтәрем/дәптерім выражает так называемую конкретную принадлежность, поскольку она дает понятие не только о самом отношении (мой), но и о том предмете, на который это отношение распространяется. Соединение этих двух особенностей в форме одного слова и составляет морфологическую категорию конкретной принадлежности. Абстрактная принадлежность выражает свою принадлежность отдельно от того предмета, на который она могла бы быть направлена.

\section{Лuтература}

1. Сопоставительная грамматика русского и казахского языков. Морфология / ред. Н. А. Баскаков, А. К. Хасенова. Алматы: Ғылым, 1966. 459 с.

2. Дмитриев Н. К. Строй тюркских языков. М., 1962. 607 с.

3. Грамматика современного башкирского литературного языка / отв. ред. А. А. Юлдашев. М.: Наука, 1981. 494 с.

4. Дмитриев Н. К. Грамматика башкирского языка. М.: Наука, 2008. 264c.

5. Зайнуллин М. В. Башкирское, тюркское и сопоставительное языкознание: Избранные статьи. Уфа: Гилем, 2012. 456 с.

6. Исследования по сравнительной грамматике тюркских языков. Ч. ІІ. Морфология. M., 1956. 366 c. 
3. И. Саляхова. Способы образования принадлежности имен существительных в башкирском и казахском языках

7. Мусабаев Г. Г. Современный казахский язык: в 3 ч. Алма-Ата: АН КазССР, 1959.

8. Юсупов Х. Г. Вопросы морфологии башкирского языка. Стерлитамак, 1991. 157 с.

9. Айғабылов А. Қазақ тілінің морфологиясы. Алматы: Санат, 1995. 136 бет.

10. Зәйнуллин М. В. Хәзерге башкорт әзәби теле. Морфология: монография. Өфө: БДУ РНУ, 2013. 353 бит.

11. Исаев С. Казіргі қазақ тіліндегі негізгі грамматикалық ұғымдар. Құрастырушы А. Ж. Құдабаев. ЖОО оку құралы. Павлодар: С. Торайғыров атындағы Павлодар мемлекеттік университеті, 2010. 178 бет.

12. Кейекбаев Ж. Ғ. Хәз̧ерге башкорт теле. Өфө: Башкортостан китап нәшриәте, 1996. 147 бит.

13. Оралбай Н. Қазіргі қазақ тілінің морфологиясы. Алматы, 2007. 388 бет.

14. Ысқақов А. Қазіргі қазаік тілі. 2-басылымы. Филология факультеттері студенттеріне арналған оқулық. Алматы: Ана тілі, 1991. 384 бет.

\section{FORMATION METHODS FOR AFFILIATIONS OF NOUNS \\ IN BASHKIR AND KAZAKH LANGUAGES}

\section{(c) Zugura I. Salyakhova}

Doctor of Philology, Associate Professor,

Head of the Department of Bashkir Philology in the Bashkir State University of Sterlitamak Branch.

49, Lenin Avenue, Sterlitamak, Republic of Bashkortostan, 453103, Russia

s.zuhra@hotmail.com

Abstract. The article is devoted to the research of the affiliation category of nouns in the Bashkir and Kazakh languages. In both the Bashkir and Kazakh languages, the category of affiliation is a grammatical category that simultaneously expresses both the object of possession and the identity of the owner, associated with one of the three persons, which are indicated by personal pronouns. This article examines indicators and forming methods of the affiliation meanings of nouns. The morphological way of the affiliation formation is analyzed, which is expressed by special affixes. The morphological-syntactic way of the affiliation forming of nouns is researched which characterized by pronouns and affiliation affixes. In the Turkic languages, including the Bashkir and Kazakh languages, a specific affiliation can be expressed in other ways. There is a so-called abstract affiliation, which expresses its affiliation separately from the object. Keywords: Bashkir language, Kazakh language, morphology, noun, category of affiliation, affix.

Статья поступила в редакиию 15.11.2020, одобрена после рецензирования 25.11.2020, принята к публикации 24.12.2020. 